\title{
IMPLEMENTASI TANGGUNG JAWAB SOSIAL PERUSAHAAN PT. TIRTA INVESTAMA DANONE AQUA DALAM PEMBERDAYAAN MASYARAKAT DI KANAGARIAN BATANG BARUS KAYU ARO KABUPATEN SOLOK ${ }^{*}$
}

\author{
"Yulia Risa, Elwidarifa Marwenny \\ Universitas Dharma Andalas, Jln Sawahan No 103A Simpang Haru Padang \\ *e-mail: yuliarisa24@gmail.com \\ e-mail: elwidarifamarwenny@gmail.com
}

\begin{abstract}
By paying attention to CSR, the company is not only oriented to the finance of the corporate (single bottom line), but also focuses on the balance between financial aspects, social aspects and environmental aspects (triple bottom line). The synergy of these three keys is the concept of sustainable development and community empowerment. This study has three aims. First, to describe and analyzed the regulation of CSR in companies engaged in natural resources. Second, to describe and analyzed the innovation of CSR strategies used by PT. Tirta Investama Danone Aqua in Empowering the communities in Kanagarian Batang Barus Kayu Aro. Third, to describe and analyzed the factors that hamper the development of CSR strategy by PT. Tirta Investama danone Aqua. This study uses an empirical juridical research method to see how the company engaged in natural resources apply the strategies and principles of Corporate Social Responsibility in realizing the community empowerment around the company. The final result that will be achieved is the CSR program by PT. Tirta Investama Kayu Aro will have a better focus on the community development and suistanable environmental development. The implementation of CSR strategic are taken by PT. Tirta Investama Danone Aqua Plan Solok. The implementer of the program entrusted to The Indonesian Family Planning Association (PKBI) in West Sumatra Province. This institution shall be responsible in conducting the CSR strategies in the society and community located around the company location.
\end{abstract}

Keyword: Corporate Social Responsibility, Community Development.

\begin{abstract}
Abstrak
Dengan memperhatikan CSR maka perusahaan tidak hanya berorientasi kepada keuangan perusahaan semata (single bottom line) akan tetapi menitik beratkan pada keseimbangan antara aspek keuangan, aspek sosial dana aspek lingkungan (tripel bottom line) sinergi dari ketiga kunci ini merupakan konsep pembangunan yang berkelanjutan dan pemberdayaan masyarakat. Oleh karena itu penelitian ini bertujuan untuk menggambarkan dan memahami pertama, pengaturan CSR pada perusahaan yang bergerak di bidang sumber daya alam Kedua, strategi CSR inovatif yang digunakan PT. Tirta Investama Danone Aqua dalam Pemberdayaan Masyarakat Kanagarian Batang Barus Kayu Aro ketiga, faktor penghambat dari pengembangan strategi CSR PT. Tirta Investama danone Aqua. Metode penelitian yang di gunakan adalah yuridis empiris untuk meneliti pelaksanaan CSR terhadap perusahaan yang bergerak di bidang sumber daya alam dalam menerapkan strategi dan prinsip-prinsip Coorporate Social Responsibility dalam aktivitas usahanya dalam mewujudkan pemberdayaan masyarakat disekitar perusahaan dijalankan. Hasil akhir yang akan diwujudkan adalah bahwa program CSR PT. Tirta Investama Kayu Aro menitik beratkan pada Community Development dan Suistanable Development, Dalam pelaksanaan CSR langkah tategis yang di lakukan oleh PT. Tirta Investama Danone Aqua Plan Solok Pelaksana programnya, dipercayakan kepada mitra Perkumpulan Keluarga Berencana Indonesia (PKBI) Provinsi Sumbar, melalui lembaga ini lah CSR di laksanakan dalam bidang sosial, ekonomi dan lingkungan.
\end{abstract}

Kata Kunci: Tanggung Jawab Sosial Perusahaan, Pemberdayaan Masyarakat.

* Naskah diterima: 09 Agustus 2018, direvisi: 23 Agustus 2018, disetujui untuk terbit: 23 September 2018 
Yulia Risa, Elwidarifa Marwenny: Implementasi Tanggung jawab Sosial Perusahaan...

\section{PENDAHULUAN}

Kini dunia usaha tidak lagi hanya memperhatikan catatan keuangan perusahaan semata (single bottom line), melainkan sudah meliputi aspek keuangan, aspek sosial, dan aspek lingkungan biasa disebut triple bottom line. Sinergi dari tiga elemen ini merupakan kunci dari konsep pembangunan berkelanjutan (sustainable development).

Menurut Undang-Undang Nomor 40 Tahun 2007 tentang Perseroan Terbatas, dalam rangka mewujudkan masyarakat adil dan makmur berdasarkan Pancasila dan UUD RI 1945, berdasarkan Ketentuan Pasal 33 ayat (4) UndangUndang Dasar Negara Republik Indonesia Tahun 1945 menyebutkan bahwa "Perekonomian nasional diselenggarakan berdasarkan atas demokrasi ekonomi dengan prinsip kebersamaan, efisiensi, berkeadilan, berkelanjutan, berwawasan lingkungan, kemandirian, serta menjaga keseimbangan kemajuan dan kesatuan ekonomi nasional". Kesejahteraan dan kemakmuran masyarakat Indonesia tidak semata-mata tanggung jawab salah satu pihak saja (swasta) akan tetapi tanggung jawab semua yang berkepentingan (stakeholders) seperti negara dan pengusaha yang ikut menikmati kekayaan Negara Republik Indonesia. Salah satu bentuk tanggung jawab pengusaha terhadap masyarakat adalah tanggungjawab sosial perusahaan yang dikenal dengan istilah "Corporate Social Responsibility (CSR)” (Hasan, Umar, 2014: 1-2).
Tanggung Jawab Sosial perusahaan bagian dari komitmen perusahaan dan dunia bisnis agar dapat memberikan dalam pengembangan ekonomi yang berkelanjutan dengan memperhatikan tanggung jawab sosial perusahaan dan menitikberatkan pada keseimbangan antara perhatian terhadap aspek ekonomis, sosial dan lingkungan (Untuang, Hendriak Budi, 2008: 1). Corporate Social Responsibility (CSR) adalah tanggung jawab sebuah organisasi terhadap dampak keputusan yang diwujudkan dalam bentuk perilaku transparan dan etis yang sejalan dengan pembangunan berkelanjutan dan kesejahteraan masyarakat (Suhartono, 2008: 9-20.)

Perkembangan dunia usaha tidak bisa dipisahkan dengan lingkungan eksternalnya, sehingga hal ini menjadi pusat perhatian bagi kalangan akademis, praktisi dan regulator serta lembaga Swadaya masyarakat (LSM) sejak beberapa dasawarsa terakhir ini. Kerja sama ekonomi kawasan, berkurangnya peran pemerintah, dan semakin dominannya peran swasta dalam pembangunan ekonomi, lebih penting lagi dari dinamika sosial tersebut adalah semakin meningkatnya kesadaran dan tuntutan masyarakat tentang Hak Azasi Manusia (HAM), keadilan, kesetaraan sosial, lingkungan hidup dan pemberdayaan (empowerring) masyarakat serta informasi dan transparansi (well imformed) atas aktivitas suatu perusahaan. Semua dinamika sosial itu tidak lepas dari berbagai dampak negatif dari 
beroperasinya suatu perusahaan (Wahyudi, Isa dan Busyra Azheri, 2008: $\mathrm{XV})$.

Pertumbuhan Perekonomian di Indonesia ekonomi tumbuh secara maju, modern dan pesat, akan tetapi perekonomian masyarakat justru berjalan lambat ini dikarenakan marginalisasi tenaga kerja lokal. Keadaan ini semakin diperparah dengan rendahnya tingkat apresiasi perusahaan terhadap tuntutan masyarakat, seperti pembebasan tanah, ganti rugi atas kerusakan lingkungan, pekerjaan (employment), pembagian keuntungan dan lain-lain sebagainya. Semua itu tidak terlepas dari kultur perusahaan yang didominasi cara berpikir dan perilaku ekonomi yang hanya berorientasi keuntungan (profit oriented), sehingga menyebabkan hubungan antara pengusaha dengan masyarakat menjadi tidak harmonis dan diwarnai berbagai konflik (Azheri, Busyra, 2010: 3).

Pelaksanaan CSR oleh perusahaan pengelola SDA belum sesuai antara idealita (harapan) dan realitas, karena ada resistensi dari perusahaan atas kewajiban CSR oleh hukum, tidak semua perusahaan dengan penuh ketaatan untuk melaksanakan (Lihat Gugatan KADIN DAN HIPMI dan beberapa Perusahaan ke Mahkamah Konstitusi atas pasal 74 Undang-Undang Nomor 40 Tahun 2007 tentang Perseroan Terbatas). Di sisi lain, Undang-Undang Nomor Nomor 40 Tahun 2007 tentang Perseroan Terbatas dan Undang-Undang Nomor 25 Tahun 2007 tentang Penanaman Modal maupun Peraturan Pemerintah Nomor 40 tahun
2012 tentang Tanggung Jawab Sosial dan Lingkungan Perseroan, belum mengatur mekanisme penerapan CSR secara komfrehensif.

Masih Banyak Perusahaan tidak mau menjalankan program-program CSR karena berpandangan hal tersebut hanya sebagai pengeluaran biaya (cost center). Pelaksanaan CSR seyogyanya memang tidak memberikan hasil secara keuangan dalam jangka pendek. tetapi CSR dapat memberikan kontribusi baik langsung maupun tidak langsung pada keuangan perusahaan di masa mendatang. Perlu dipahami bahwa dinamika perkembangan lingkungan perusahaan berjalan sedemikan cepat, sehingga membutuhkan berbagai inovasi dan kreasi Program CSR yang mampu dirasakan secara optimal oleh masyarakat disekitar perusahaan. Perubahan lingkungan perusahaan tersebut seperti adanya tuntutan otonomi daerah, sehingga harapan/cita-cita kesejahteraan masyarakat menjadi semakin tinggi, sedangkan kemampuan pemerintah daerah dalam pengelolaan anggaran untuk pembangunan masih terbatas. Di sinilah peran CSR perusahaan.

Untuk memenuhi kebutuhan air minum yang sehat dan berkualitas bagi Masyarakat Sumatera Barat. Tahun 2013 PT Tirta Investama Danone Aqua Kayu Aro merupakan perusahaan AQUA Grup mendirikan pabrik yang ke-17 di Indonesia,yang berlokasi di Jorong Kayu Aro, Kanagarian Batang Barus, Kecamatan Gunung Talang, Kabupaten Solok. AQUA telah hadir di Indonesia 
Yulia Risa, Elwidarifa Marwenny: Implementasi Tanggung jawab Sosial Perusahaan...

sejak tahun 1973, dengan misi untuk memberikan kesehatan kepada masyarakat Indonesia melalui produk minuman yang sehat dan berkualitas.

Program dan kegiatan CSR berbasis sosial dan lingkungan telah dilaksanakan PT. Tirta Investama Danone Aqua pada masyarakat di sekitar Kanagarian Batang Barus yang di wujudkan dalam bentuk AQUA Lestari yang dikembangkan sejak tahun 2006 sebagai payung inisiatif keberlanjutan dengan menggunakan DANONE WAY dan ISO 26000 sebagai referensi. AQUA Lestari direalisasikan dengan melaksanakan berbagai inisiatif sosial dan lingkungan yang mencakup wilayah sub-Daerah Aliran Sungai (DAS) secara terintegrasi dari wilayah hulu, tengah, dan hilir di lokasi AQUA Group beroperasi yang disesuaikan dengan konteks lokal. Berbagai inisiatif tersebut berada di bawah empat pilar, yaitu: Pelestarian Air dan Lingkungan, Praktik Perusahaan Ramah Lingkungan, Pengelolaan Distribusi Produk, serta Pelibatan dan Pemberdayaan Masyarakat.

\section{METODE PENELITIAN}

Metode Pendekatan yang digunakan adalah menggunakan metode pendekatan yuridis sosiologis (empiris) yaitu penelitian yang berlandaskan pada kaidah-kaidah hukum yang dilihat dari segi penerapannya. Sedangkan sifat Penelitian yang dilakukan dalam penelitian ini adalah deskriptif analitis yaitu penelitian ini diharapkan dapat diperoleh gambaran yang menyeluruh dan lengkap mengenai implementasi tanggung jawab sosial perusahaan (corporate social responsibility) PT. Tirta Investama Aqua Danone dalam Pemberdayaan Masyarakat di Kanagarian Batang Barus, Kayu Aro. Melalui penelitian yuridis empiris ini dapat dilihat bagaimana perusahaan yang bergerak di bidang sumber daya alam menerapkan strategi dan prinsip-prinsip Coorporate Social Responsibility dalam aktivitas usahanya dalam mewujudkan pemberdayaan masyarakat di sekitar perusahaan. Namun sebelum melihat penerapannya, terlebih dahulu juga dipahami tentang pengaturan prinsipprinsip CSR yang berkaitan dengan ketentuan peraturan perundang-undangan. Sedangkan untuk mengetahui makna dibalik pengaturan prinsip-prinsip CSR itu sendiri, digunakan metode penelitian yang bersifat kualitatif.

\section{HASIL DAN PEMBAHASAN}

\section{Pengaturan CSR Pada Perusahaan Yang Bergerak Di Bidang Sumber Daya Alam.}

Pengaturan CSR dalam peraturan perundang-undangan di Indonesia, bukan lah hal yang baru, Sejumlah peraturan perundang-undangan, telah mengatur mengenai CSR tersebut. Ada tujuh pengaturan yang terkait dengan CSR adalah sebagai berikut:

\section{1) Undang-Undang Badan Usaha Milik Negara (BUMN)}

Menurut Pasal 2 ayat (1) huruf e Undang-Undang Nomor 19 Tahun 2003 tentang Badan Usaha Milik Negara (UU BUMN) salah satu tujuan dibentuknya BUMN diantaranya adalah "turut aktif memberikan bimbingan dan bantuan 
kepada pengusaha golongan ekonomi lemah, koperasi dan masyarakat". Untuk itu pemerintah mengemas keterlibatan BUMN sebagai upaya pemerintah dalam rangka memperkuat program kemitraan, maka melalui Peraturan Menteri Negara BUMN nomor PER-05/MBU/2007 tentang Program Kemitraan Badan Usaha Milik Negara dengan Usaha Kecil dan Program Bina Lingkungan. Sedangkan sumber dana dari Program Kemitraan dan Program Bina Lingkungan (PKBL) sebagaimana dijelaskan Pasal 9 Peraturan Menteri Negara BUMN sebagai berikut :

1. Dana Program Kemitraan bersumber dari :
a. Penyisihan laba setelah pajak maksimal sebesar 2\% (dua persen);
b. Jasa administrasi pinjaman/marjin/bagi hasil, bunga deposito dan/atau jasa giro dari dana Program Kemitraan setelah dikurangi beban operasional;
c. Pelimpahan dana Program Kemitraan dari BUMN lain, jika ada.

2. Dana Program Bina Lingkungan (BL) bersumber dari :
d. Penyisihan laba setelah pajak maksimal sebesar 2\% (dua persen);

e. Hasil bunga deposito dan atau jasa giro dari dana Program BL.

Menurut ketentuan Pasal 11 Peraturan Menteri Negara BUMN ditegaskan bahwa Dana Program Kemitraan diberikan dalam bentuk :
1. Pinjaman untuk membiayai modal kerja dan atau pembelian aktiva tetap dalam rangka meningkatkan produksi dan penjualan;

2. Pinjaman khusus untuk membiayai kebutuhan dana pelaksana kegiatan Mitra Binaan yang bersifat pinjaman tambahan dan berjangka pendek dalam rangka memenuhi pesanan dari rekanan usaha Mitra Binaan.

3. Beban Pembinaan meliputi hal-hal sebagai berikut :

a. Untuk membiayai pendidikan, pelatihan, pemagangan, pemasaran, promosi, dan hal-hal lain yang menyangkut peningkatan produktivitas Mitra Binaan serta untuk pengkajian/penelitian yang berkaitan dengan Program Kemitraan;

b. Beban pembinaan bersifat hibah dan besarnya maksimal $20 \%$ (dua puluh persen) dari dana Program Kemitraan yang disalurkan pada tahun berjalan.

\section{2) Undang-Undang Perseroan Terbatas}

CSR yang dimaksud dalam UUPT secara terminologi ada perbedaan dengan CSR yang ada di UUPM, karena dalam UUPT menggunakan terminologi tanggung jawab sosial dan lingkungan (TJSL). Ketentuan ini dapat dilihat pada rumusan Pasal 1 angka 3 UUPT dan judul Bab $\mathrm{V}$ yang hanya terdiri atas 1 (satu) pasal yaitu Pasal 74 yang terdiri dari 4 (empat) ayat yaitu sebagai berikut : 
Yulia Risa, Elwidarifa Marwenny: Implementasi Tanggung jawab Sosial Perusahaan...

1) Pasal 74 ayat (1) UUPT Perseroan menegaskan bahwa perusahaan yang menjalankan kegiatan usahanya di bidang dan/atau berkaitan dengan sumber daya alam wajib melaksanakan Tanggung Jawab Sosial dan Lingkungan. Ketentuan ini lebih mengedepankan prinsip berwawasan lingkungan dalam CSR. Hal terlihat dari pembebanan kewajiban TJSL hanya pada perusahaan yang menjalankan kegiatan dan/atau berkaitan dengan sumber daya alam. Sehingga secara makna gramatikal perusahaan yang tidak menjalankan dan/atau berkaitan dengan sumber daya alam tidak wajib menerapkan TJSL dalam aktivitas usahanya.

2) Pasal 74 ayat (2) UUPT menyatakan bahwa TJSL merupakan kewajiban Perseroan yang dianggarkan dan diperhitungkan sebagai biaya Perseroan dilaksanakan dengan memperhatikan kepatutan dan kewajaran. Kata-kata "kepatutan" dan "kewajaran" merupakan terminologi yang bermakna pada asas hukum yang perlu penafsiran yang tegas. Ketentuan ini sejalan dengan prinsip akuntabilitas dalam CSR.

3) Pasal 74 ayat (3) UUPT Perseroan menegaskan bahwa perusahaan yang tidak melaksanakan kewajiban sebagaimana dimaksud ayat (1) dikenakan sanksi sesuai dengan ketentuan peraturan perundangundangan. Ketentuan ini semakin mempertegas bahwa TJSL telah dinyatakan sebagai kewajiban dalam makna liability karena diikuti sanksi bagi perseroan yang tidak menerapkannya. Ketentuan ini sejalan dengan prinsip taat hukum dalam CSR.

\section{3) Undang-Undang Penanaman Modal}

Landasan filosofis pembentukan peraturan di bidang ekonomi termasuk Undang-undang Nomor 25 Tahun 2007 tentang Penanaman Modal (UUPM) yaitu Pasal 33 ayat (4) UUD 1945 yang menegaskan bahwa "Perekonomian nasional diselenggarakan berdasarkan atas demokrasi ekonomi dengan prinsip kebersamaan, efisiensi, berkeadilan, berkelanjutan, berwawasan lingkungan, kemandirian, serta dengan menjaga keseimbangan kemajuan dan kesatuan ekonomi nasional". Prinsip demokrasi ekonomi ini pada dasarnya mengandung makna bagaimana menjadikan bangsa Indonesia menjadi negara yang mampu mensejahterakan rakyat nya.Konsep ini oleh founding fathers disebutnya dengan negara kesejahteraan (welfare state).

Dilihat dari substansi UUPM terdapat beberapa pasal yang secara esensial berkaitan dengan CSR yaitu :

a. Pasal 3 ayat (1) UUPM mengenai asas penanaman modal yang terdiri atas asas kepastian hukum, asas keterbukaan, asas akuntabilitas, asas perlakuan yang sama dan tidak membedakan asal negara, asas kebersamaan, asas efisiensi berkeadilan, asas berkelanjutan, asas berwawasan lingkungan, asas 
kemandirian, dan asas Keseimbangan kemajuan dan kesatuan ekonomi nasional. Asas penamanan modal ini sejalan dengan prinsip CSR yaitu keterbukaan (disclosure), akuntabilitas, non diskriminatif, berkelanjutan, dan berwawasan lingkungan.

b. Pasal 10 UUPM yang berkaitan dengan ketenagakerjaan yang menegaskan adanya keharusan mengutamakan tenaga kerja WNI, kewajiban meningkatkan kompetensi tenaga kerja WNI melalui pelatihan kerja dan perusahaan yang mempekerjakan tenaga kerja asing diwajibkan menyelenggarakan pelatihan dan melakukan alih teknologi kepada tenaga kerja WNI. Ketentuan ini lebih mengedepankan prinsip CSR dalam bentuk human capital dan pendidikan.

c. Pasal 15 UUPM berkaitan dengan kewajiban penanaman modal, dimana setiap penanam modal berkewajiban:

a) Menerapkan prinsip tata kelola perusahaan yang baik;

b) Melaksanakan tanggung jawab sosial perusahaan;

c) Membuat laporan tentang kegiatan penanaman modal dan menyampaikannya kepada Badan Koordinasi Penanaman Modal;

d) Menghormati tradisi budaya masyarakat sekitar lokasi kegiatan usaha penanaman modal; dan

e) Mematuhi semua ketentuan peraturan perundang-undangan.

d. Pasal 17 UUPM berkaitan dengan kewajiban setiap penanam modal yang bergerak di bidang usaha yang berkaitan dengan sumber daya alam yang tidak terbarukan untuk mengalokasikan sebagian dananya untuk pemulihan lokasi usahanya sehingga memenuhi standar lingkungan hidup. Ketentuan ini sejalan dengan prinsip berwawasan lingkungan dalam CSR.

e. Pasal 34 UUPM berkaitan dengan sanksi bagi badan usaha atau perseorangan yang tidak melaksanakan kewajibannya termasuk CSR. Dengan adanya ketentuan sanksi, semakin menguatkan bahwa CSR itu tidak lagi bersifat voluntary, tetapi merupakan kewajiban hukum (legal responsibility) bagi semua badan usaha dan perseorangan, sehingga mencerminkan prinsip taat hukum.

\section{4) Undang-Undang Nomor 13 Tahun 2011 Tentang Penanganan Fakir Miskin.}

Undang-undang ini tidak membahas secara khusus peran dan fungsi perusahaan dalam menangani fakir miskin, melainkan terdapat klausul dalam pasal 36 ayat 1 "Sumber pendanaan dalam penanganan fakir miskin, meliputi: c. dana yang disisihkan dari perusahaan perseroan. Diperjelas dalam ayat 2 Dana yang disisihkan dari perusahaan perseroan sebagaimana dimaksud pada ayat (1) huruf digunakan sebesarbesarnya untuk penanganan fakir miskin. Sedangkan pada Pasal 41 tentang "Peran Serta Masyarakat", dalam ayat 3 dijelaskan bahwa "Pelaku usaha 
Yulia Risa, Elwidarifa Marwenny: Implementasi Tanggung jawab Sosial Perusahaan...

sebagaimana dimaksud pada ayat (2) huruf $j$ berperan serta dalam menyediakan dana pengembangan masyarakat sebagai pewujudan dari tanggung jawab sosial terhadap penanganan fakir miskin.

5) Undang-Undang Minyak Dan Gas Bumi Nomor 22 Tahun 2001.

Dalam pasal 13 ayat 3 (p) disebutkan: Kontrak Kerja Sama sebagaimana dimaksud dalam ayat (1) wajib memuat paling sedikit ketentuan-ketentuan pokok yaitu: (p) pengembangan masyarakat sekitarnya dan jaminan hak-hak masyarakat adat".

6) Peraturan Pemerintah Nomor 47 Tahun 2012 Tentang Tanggung Jawab Sosial Dan Lingkungan.

PP ini melaksanakan ketentuan Pasal 74 Undang-Undang Nomor 40 Tahun 2007. Dalam PP ini, perseroan yang kegiatan usahanya di bidang dan/atau berkaitan dengan sumber daya alam diwajibkan untuk melaksanakan tanggung jawab sosial dan lingkungan. Kegiatan dalam memenuhi kewajiban tanggung jawab sosial dan lingkungan tersebut harus dianggarkan dan diperhitungkan sebagai biaya Perseroan yang dilaksanakan dengan memperhatikan kepatutan dan kewajaran.
7) Peraturan Menteri Sosial RI Nomor 13 Tahun 2012 Tentang Forum Tanggung Jawab Dunia Usaha Dalam Penyelenggaraan Kesejahteraan Sosial.

Kementrian Sosial memandang penting dibentuknya forum CSR pada level Provinsi, sebagai sarana kemitraan antara pemerintah dengan dunia usaha. Rekomendasi Permensos adalah dibentuknya Forum CSR di tingkat provinsi beserta pengisian struktur kepengurusan yang dikukuhkan oleh Gubernur.

Dari pengaturan CSR diatas, urusan CSR merupakan domain pemerintah pusat, karena baik Peraturan Menteri BUMN, Undang-Undang PT, UndangUndang PMA, Undang-Undang Minyak dan Gas Bumi dibuat oleh DPR bersama Pemerintah Pusat. Sedangkan peran pemerintah daerah adalah melakukan monitoring dengan perangkat Analisis Mengenai Dampak Lingkungan dan Sosial (Amdalsos) dan mengkaji sejauhmana perusahaan mampu memberikan manfaatnya kepada stakeholder dalam hal ini masyarakat setempat. Pemda tidak berkewenangan dalam mengatur CSR yang merupakan urusan program perusahaan terlebih masalah pengelolaan dananya, kecuali menjalin kerjasama antar stakeholder didasarkan pada program dan skala prioritas yang sama terkait upaya pemenuhan kebutuhan masyarakat setempat. 


\section{Strategi CSR inovatif yang} digunakan PT. Tirta Investama Danone Aqua Dalam Pemberdayaan Masyarakat Kanagarian Batang Barus Kayu Aro

CSR adalah Komitmen sektor usaha dalam menjalankan operasi bisnisnya dengan menerapkan etika dalam berbisnis maka akan dapat meningkatkan kualitas hidup karyawan dan masyarakat sekitar lingkungan perusahaan serta bekerja sama dengan pemangku kepentingan dalam masyarakat untuk mewujudkan kesejahteraan sosial dan lingkungan yang pada akhirnya dapat mewujudkan pengembangan masyarakat dan pembangunan berkelanjutan.

AQUA adalah produk pelopor air minum dalam kemasan di Indonesia yang didirikan tahun 1973. AQUA bersumber dari air pegunungan alami yang mengandung mineral seimbang yang menyehatkan. AQUA Grup mendirikan pabrik yang ke-17 di Indonesia, yang berlokasi di Jorong Kayu Aro, Kanagarian Batang Barus, Kecamatan Gunung Talang, Kabupaten Solok- Sumatera Barat.

Pelaksanaan Tanggung jawab sosial perusahaan AQUA Group berawal dari pemikiran Riboud, tentang komitmen ganda perusahaan. Komitmen ganda merupakan cara menjalankan bisnis yang mengedepankan keseimbangan antara keberhasilan ekonomi dan kemajuan sosial. Pemikiran tersebut sejalan dengan pemikiran pendiri AQUA, Tirto Utomo, yang berprinsip bahwa bisnis harus berkontribusi sosial pada masyarakat. (Profil PT. Tirta Investama Aqua Danone).

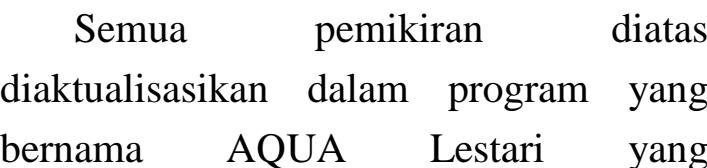
dikembangkan sejak tahun 2006 sebagai wujud yang keberlanjutan dengan menggunakan DANONE WAY dan ISO 26000 sebagai referensi. AQUA Lestari direalisasikan dengan melaksanakan berbagai inisiatif sosial dan lingkungan yang mencakup wilayah sub- Daerah Aliran Sungai (DAS) secara terintegrasi dari wilayah hulu, tengah, dan hilir di lokasi AQUA Group beroperasi yang disesuaikan dengan konteks lokal. Berbagai inisiatif tersebut berada di bawah empat pilar, yaitu: Pelestarian Air dan Lingkungan, Praktik Perusahaan Ramah Lingkungan, Pengelolaan Distribusi Produk, serta Pelibatan dan Pemberdayaan Masyarakat (Profil Perusahaan PT.TIV).

Seluruh inisiatif sosial dan lingkungan, merupakan implementasi komitmen berkelanjutan AQUA Group yang berada di bawah payung AQUA Lestari. Ada empat pilar yang mendukung AQUA Lestari:

1. Pelestarian air dan lingkungan

Upaya AQUA Group untuk menjalankan manajemen sumber daya air yang berkelanjutan, baik untuk operasional bisnis maupun untuk kepentingan sosial masyarakat melalui keseimbangan neraca air, pengendalian kualitas air dan pengelolaan sumber daya 
Yulia Risa, Elwidarifa Marwenny: Implementasi Tanggung jawab Sosial Perusahaan...

air. Program yang dilaksanakan antara lain penelitian-penelitian terkait sumber daya air, pendidikan lingkungan hidup, rehabilitasi saluran irigasi, penanaman pohon penghijauan serta pembuatan sumur resapan (biopori).

\section{Praktik Perusahaan Ramah Lingkungan}

AQUA Group menjalankan operasi bisnis dengan mengedepankan nilai-nilai Hak Asasi Manusia, kesehatan dan keselamatan kerja sesuai dengan kebijakan WISE kualitas dan kepatuhan kepada peraturan dan perundangundangan yang berlaku. Program yang dilaksanakan antara lain pengurangan jejak karbon dengan melakukan penghematan energi, air, bahan baku plastik dan kemasan, serta manajemen lingkungan dengan melakukan audit lingkungan GREEN.

\section{Pengelolaan Distribusi Produk}

AQUA Group berusaha mengelola dampak potensial proses pendistribusian produk dari pabrik ke konsumen. Hal ini dilakukan antara lain dengan menjajaki penggunaan mode transportasi altarnatif (kereta api), safety riding, perbaikan atau perawatan jalan, serta pemberdayaan pemulung dalam konteks pengelolaan sampah.

\section{Pelibatan dan Pemberdayaan Masyarakat}

AQUA Group mengambil inisiatif untuk penguatan kemandirian sosial ekonomi masyarakat agar tercipta kohesi sosial. Program yang dilaksanakan antara lain pertanian organik terpadu, usaha mikro dan koperasi, akses masyarakat terhadap modal dan pasar, akses masyarakat terhadap air bersih dan penyehatan lingkungan serta program tanggap bencana.

Kehadiran AQUA di seluruh Indonesia, termasuk di Solok senantiasa memperhatikan faktor lingkungan dan sosial. Dalam pelaksanaan nya langkah stategis yang di lakukan oleh PT. Tirta Investama Plan Solok Pelaksanaan programnya, dipercayakan kepada mitra Perkumpulan Keluarga Berencana Indonesia (PKBI) Provinsi Sumbar. (wawancara dengan Bapak Wali Nagari Batang Barus, Bapak Syamsul Azwar). Kegiatan diawali dengan pemilihan sumber air yang seksama melalui kriteria, proses dan tahapan yang melibatkan para ahli yang kompeten di bidangnya, antara lain ahli geologi, hidrogeologi dan lainnya. Dalam proses produksi pemanfaatan air tanah dalam sebagai sumber air AQUA, telah dipastikan melalui penelitian mendalam agar tidak berhubungan dengan air permukaan, yang biasanya digunakan oleh masyarakat untuk keperluan sehari-hari misalnya untuk sumur warga, irigasi dan sebagainya.

Kegiatan CSR Aqua dilakukan di seluruh pabrik yang ada di Indonesia. Tidak terkecuali di Kayu Aro Solok, Bahwa proses pelestarian lingkungan di Solok telah dimulai sejak pabrik dibangun." Kegiatan sosial dan lingkungan telah dijalankan sejak perusahaan didirikan Tahun 2012, dan tetap akan berlanjut sampai ke depannya. 
Bentuk Kegiatannya adalah pembuatan fasilitas air bersih dan sanitasi untuk beberapa dusun, pengembangan program pertanian berkelanjutan, penanaman pohon sekitar pabrik, renovasi MCK \& tempat wudhu untuk beberapa masjid dan mushola di 5 jorong di Kayu Aro, pemberian bantuan air minum untuk pada korban banjir di Padang, serta beberapa kegiatan lingkungan dan aktivitas masyarakat di Kayu Aro dan sekitarnya.( Wawancara dengan Bapak Izrai Tanggal 15 Mei 2018).

Sejak awal PT. Tirta Investama (AQUA) Unit Usaha Kayu Aro berupaya agar semua pemangku kepentingan ikut merasakan manfaat kehadiran perusahaan di tengah-tengah masyarakat di Kanagarian Batang Barus. Dimana harus memberikan kontribusi positif kepada masyarakat (people) dan ikut aktif dalam menjaga kelestarian lingkungan (planet). Adapun bentuk kegiatan CSR yang dilakukan oleh PT. Tirta Investama Unit Usaha Kayu Aro adalah:

\section{1) Bidang Sosial}

\section{a. Sanitasi Lingkungan Berbasis Masyarakat}

Dari data on line STBM Smart 2016, bahwa tingkat akses sanitasi masyarakat kabupaten Solok berada pada urutan ke 15 di provinsi Sumatera Barat. Sedangkan di tingkat Kabupaten, Kecamatan Gunung Talang berada diurutan keenam. Dari kondisi tersebut dapat dikatakan, bahwa tingkat akses sanitasi masyarakat baik yang berada di kabupaten Solok maupun di kecamatan Gunung Talang dikategorikan masih kurangnya pemahaman mereka tentang kesehatan lingkungan dan hidup bersih. Masih banyak masyarakat yang BAB sembarang tempat dan belum mengelola sampah dan limbah rumah tangga dengan baik. Dari hasil survei atau assessment yang sudah dilakukan terkait dengan kehidupan masyarakat menunjukkan bahwa masyarakat sangat sering terkena penyakit diare baik orang dewasa maupun anakanak dan balita. Hal ini kemungkinan berasal dari pola hidup masyarakat yang tidak sehat terutama yang berasal dari makanan dan lingkungan tempat tinggal. Sekitar $50 \%$ masyarakat memiliki jamban, namun pengelolaan sampah rumah dan limbah rumah tangga tidak diperhatikan dengan baik.

Sebagai salah satu perusahaan yang sangat peduli dengan kehidupan masyarakat di sekitar operasional pabrik bermitra dengan lembaga sosial di Sumatera Barat, berusaha memberikan pemahaman terhadap masyarakat untuk mengajak berperilaku hidup bersih dan sehat sebagaimana yang dicanangkan oleh pemerintah kabupaten Solok dalam 4 pilar pembangunan yaitu meningkatkan kesehatan masyarakat.

Program Sanitasi Total Berbasis Masyarakat (STBM) adalah merupakan pendekatan untuk merubah perilaku orang menjadi lebih bersih dan sehat melalui pemberdayaan masyarakat dengan metode pemicuan. STBM adalah satu-satunya pendekatan perubahan perilaku yang menyasar langsung ke tingkat rumah tangga, khususnya melalui penerapan ke5 pilar STBM. Sampai saat ini, walau 
Yulia Risa, Elwidarifa Marwenny: Implementasi Tanggung jawab Sosial Perusahaan...

mengusung prinsip non-subsidi, STBM terbukti mampu meningkatkan akses sanitasi dan perubahan perilaku higiene dengan cepat. (wawancara dengan Bapak Izrai, 25 Juni 2018).

Project STBM yang dilakukan bersama mitra sejak tahun 2016-2017 adalah di Nagari Batang Barus tepatnya di jorong Kayu Aro dan jorong Kayu Jao. Adapun kegiatan ini dibagi dalam 3 tahap yaitu, pra pemicuan, pemicuan dan pasca pemicuan. Pada tahap pra pemicuan lebih cenderung untuk melihat kondisi di lokasi program melalui assessment, pertemuan dengan kelompok masyarakat dan melakukan pelatihan-pelatihan. Sedangkan pada tahap pemicuan adalah menyampaikan metode metode STBM yang menyebabkan masyarakat terpicu untuk merubah perilaku mereka dari kebiasaan sebelumnya kearah yang lebih baik. Setelah masyarakat merasa terpicu maka mereka sadar dengan apa yang sudah mereka alami selama ini bukanlah hal yang baik dan berdampak buruk terhadap kesehatan mereka. Setelah masyarakat terpicu, pada tahap pasca pemicuan tanpa adanya paksaan dengan sendirinya mereka dapat merubah pola hidup kearah yang lebih baik seperti yang terutuang pada 5 pilat STBM, seperti :

1. Stop buang air besar sembarangan

2. Cuci tangan pakai sabun;

3. Pengelolaan air minum/makanan rumah tangga

4. Pengelolaan sampah rumah tangga

5. Pengelolaan limbah cair rumah tangga

Dilakukan melalui Pembangunan Sarana Akses Air Bersih Dan Penyehatan Lingkungan

\begin{tabular}{|c|c|c|}
\hline $\begin{array}{c}\text { Nama } \\
\text { Jorong }\end{array}$ & Tahun & Bentuk Kerja sama \\
\hline \multirow[t]{7}{*}{$\begin{array}{l}\text { Kayu } \\
\text { Aro }\end{array}$} & 2010 & $\begin{array}{lrr}\text { Kerja } & \text { sama } & \text { dengan } \\
\text { Yayasan } & \text { Solidaritas Anak } \\
\text { Bangsa } & \text { Indonesia } \\
\text { (YASABI) } & \end{array}$ \\
\hline & & $\begin{array}{l}\text { 1) Pembangunan } \\
\text { MCK }\end{array}$ \\
\hline & & 2) 3 reservoar \\
\hline & & 3) $3 \mathrm{Tab}$ Stand \\
\hline & & $\begin{array}{l}\text { 4) Pipa jaringan utama } \\
\text { sepanjang } 5.600 \mathrm{~m}\end{array}$ \\
\hline & 2012 & $\begin{array}{l}\text { Kerja sama dengan } \\
\text { kelompok masyarakat } \\
\text { 1) Pembangunan pipa } \\
\text { jaringan utama } \\
\text { sepanjang } 1.300 \mathrm{~m} \\
\text { 2) } 2 \text { tangki reservoar }\end{array}$ \\
\hline & 2015 & $\begin{array}{l}\text { Kerja sama } \\
\text { Perkumpulan } \\
\text { Berencana } \\
\text { Keluarga } \\
\text { (PKBI) Sumbar } \\
\text { 1) Pembanesia } \\
\text { jaringan } \\
\text { sepanjang } 1.100 \mathrm{~m} \\
\text { 2) } 2 \text { reservoar } \\
\text { 3) } 22 \text { sambunan rumah, } \\
\text { mushalla dan SDN } 40\end{array}$ \\
\hline $\begin{array}{l}\text { Lubuk } \\
\text { Selasih }\end{array}$ & 2014 & 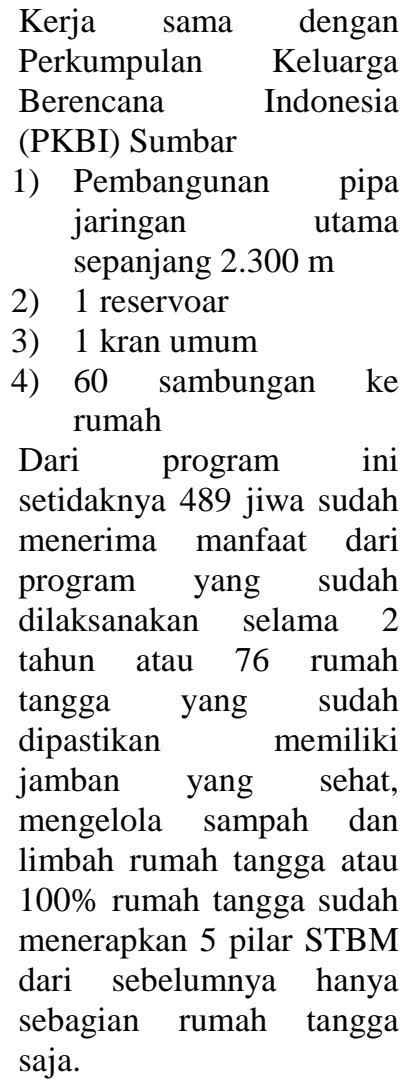 \\
\hline
\end{tabular}




\section{b. Konservasi Berbasis \\ Masyarakat (Sekolah Lapangan Alpukat)}

Sejak bulan Juli 2015 yang lalu, Yayasan FIELD Indonesia sebagai mitra pelaksana program tanggung jawab sosial perusahaan (CSR) pabrik AQUA Solok telah mendampingi warga belajar di Jorong Kayu Aro untuk belajar bersama tentang pertanian berkelanjutan. Sekolah Lapangan (SL) adalah suatu bentuk proses belajar masyarakat yang berkumpul sekali seminggu untuk mengikuti proses belajar. Bentuk yang dilakukan oleh warga belajar seperti menganalisa perkembangan tanaman dari fase demi fase serta mendalami berbagai prinsip terkait perkembangan dinamika tanaman akibat faktor alam seperti populasi serangga, fisiologi dan kompensasi tanaman, pemeliharaan kesuburan tanah, pengaruh air dan cuaca, pemilihan varietas, dan lain-lain, melalui eksperimen-eksperimen yang mereka lakukan sendiri. Selanjutnya kegiatan pokok, dilakukan adalah untuk memitigasi masalah-masalah yang dihadapi masyarakat. Dalam proses ini diharapkan masyarakat dapat berpartisipasi secara penuh dalam belajar dan pengambilan keputusan. (Data Laporan Pelaksanaan CSR PT TIV)

Sebelum proses SL dilakukan warga diajak terlebih dahulu melihat permasalahan yang ada di jorong mereka dan mengkaji metode kehidupan berkelanjutan (Sustainable Livelihood Assessment/SLA) diambil sebagai alat proses diskusi dan mengambil keputusan bersama. Hasil dari SLA adalah sebagai dasar dalam mengambil keputusan untuk membuat suatu rencana aksi atau kegiatan dalam memitigasi kendala yang ada.

Jorong Kayu Aro:

Kerjasama dengan Yayasan FIELD Indonesia (2015)

Tujuan:

a) Mencari solusi dan metode terbaik melalui sekolah lapangan agar dapat memelihara tanaman alpukat bisa tumbuh dengan baik dan hasilnya berkualitas.

b) Menjaga kelestarian lingkungan di sekitar pabrik agar tetap dikelola dengan baik bersama masyarakat dengan menanam pohon buah di sekitar sumber mata air.

\section{c. Membangun Taman Keanekaragaman Hayati (Kehati) 2014-Sekarang}

Taman Kehati atau Taman Kota adalah salah satu program yang dikembangkan oleh semua pabrik AQUA Group yang ada di Indonesia. Tujuan utama program pengembangan Taman Kehati ini adalah sebagai sarana ruang terbuka hijau, sebagai koleksi tumbuhan endemik lokal, sebagai kawasan konservasi in-situ dan ex-situ guna menyelamatkan dan mengembangkan berbagai jenis flora dan fauna. Selain itu keragaman hayati juga berfungsi untuk mendukung sistem kehidupan seperti penjaga kualitas tanah, penyimpanan air tanah dan menjaga siklus karbon dan nutrisi. Yang dimaksud dengan kehati 
Yulia Risa, Elwidarifa Marwenny: Implementasi Tanggung jawab Sosial Perusahaan...

lokal adalah spesies atau sumber daya genetik tumbuhan dan satwa endemik yang hidup berkembang secara alami di daerah tertentu.

Berdasarkan keputusan dari manajemen AQUA Group khususnya PT Tirta Investama Pabrik Solok sudah menyiapkan lahan lebih dari 2 hektar yang diperuntukan sebagai lokasi pengembangan Taman Kehati Pabrik AQUA Solok. Hal ini dilakukan dalam rangka untuk memenuhi persyaratan pencapaian proper hijau pabrik yang mana pembangunannya sudah dilaksanakan sejak pertengahan tahun 2014 yang lalu bekerjasama dengan vendor lokal dengan melibatkan masyarakat setempat mulai dari perencanaan, penataan, penanaman dan pengelolaannya.

Di lahan yang berlokasi di belakang pabrik AQUA tersebut sudah ditanam 74 jenis pohon endemik Sumatera Barat. Semua jenis tumbuhan yang sudah ditanam tersebut berasal dari anakan yang sengaja dicari di hutan. Sampai saat ini 222 pohon sudah ditanam yang terdiri dari 3 pohon setiap jenisnya. Dikarenakan pembuatan taman tersebut tergolong baru masih banyak kekurangannya dari persyaratan sebagai Taman Kehati. Untuk itu pabrik AQUA melalui program Corporate Social Responsibility (CSR) merencanakan pengembangannya selama 4 tahun ke depan.

Rencana pengembangan Taman Kehati selama 5 tahun ini, AQUA akan berkoordinasi dengan pihak-pihak terkait untuk mendapatkan dukungan. Sampai saat ini selain penanaman pohon endemik sudah dibangun jalur pejalan kaki, kolam ikan dan sumur resapan. Selian itu ada beberapa persyaratan lainnya yang harus dilakukan diantaranya, pembuatan pangkalan data taman, denah, leter nama taman, nama masing-masing pohon dan infrastruktur pendukung lainnya. Diharapkan taman tersebut mendapat dukungan dari berbagai pihak dan dapat dimanfaatkan sebagaimana mestinya.

Tujuan:

a) Sebagai sarana ruang terbuka hijau (2,5 ha lahan AQUA dijadikan sebagai Taman Kehati)

b) Sebagai koleksi tumbuhan endemik lokal (74 jenis tanaman lokal yang sudah ditanam)

c) Sebagai kawasan konservasi in-situ dan ex-situ guna menyelamatkan dan mengembangkan berbagai jenis flora dan fauna.

d) Sebagai salah satu syarat untuk proper pabrik.

\section{2) Dibidang Ekonomi}

Dilakukan dalam bentuk donasi:

1. Perbaikan Saluran Irigasi

Tahun 2011: Perbaiki saluran irigasi Banda Lohong di Kayu Aro

Tahun 2016: Perbaiki saluran irigasi Banda Bukik di Kayu Aro

2. Bedah 5 Tempat Berwuduk Mushalla Tahun 2010: Mushalla Darussalam di Kayu Aro

Tahun 2011: Mushalla Taqwa di Kayu Aro 
Tahun 2013: Mushalla Nurul Yaqin, Mushalla Nurul Mukminin, Mushalla Firdaus

\section{PMTAS}

Tahun 2014: Kerja sama dengan PKK Kabupaten Solok di SDN 38 Koto Gaek Guguak dan SDN 22 JawiJawi Guguak

Tahun 2015: Kerja sama dengan PKK Nagari Batang Barus: PMT di 10 Posyandu di Nagari Batang Barus

4. Aqua Solok Berbagi Hewan Qurban Sejak tahun 2013 setiap tahunnya AQUA selalu berbagi hewan qurban. Setiap tahunnya 3 ekor sapi diserahkan ke Nagari Batang Barus sebagai hewan qurban.

5. PT. Tirta Investama Aqua Solok mengadakan acara Buka Bersama Dan berbagi dengan Anak Yatim.

Ada 67 orang anak yatim di Jorong Kayu Aro diundang untuk berbuka puasa bersama. Setelah berbuka puasa bersama dilanjutkan pembagian paket untuk keperluan anak yatim. Sebagai rasa syukur atas peresmian Pabrik sekaligus untuk merayakan hari Kemenangan, AQUA Solok menyerahkan paket Lebaran kepada anak yatim dari Jorong Kayu Aro Nagari Batang Barus. Paket yang diserahkan pada 5 Agustus 2013 di Kantor AQUA Solok ini berisikan kain sarung, minyak makan, gula pasir, sirup dan beras.
3. Hambatan Hambatan Yang di Hadapi Oleh PT. Tirta Investama Danone Aqua Unit Usaha Danau Kembar Dalam Pelaksanaan CSR.

Dalam pelaksanaan CSR PT. Tirta Investama Danone Aqua Unit Usaha Danau Kembar mendapatkan Penghargaan disampaikan pada ajang apresiasi terhadap komitmen perusahaan dan menjalankan program CSR yang diselenggarakan oleh Corporate Forum for Community Development (CFCD) bekerjsama dengan Kementerian Koordinator Bidang Pembangunan Manusia dan Kebudayaan (Kemenko PMK) Republik Indonesia dalam pelaksanaan percepatan pencapaian Millenium Development Goals (MDGs). Tahun 2014: Program Pembangunan Sarana Akses Air Bersih dan Penyehatan Lingkungan di Kayu Aro Tahun 2015: Program Pembangunan Sarana Akses Air Bersih dan Penyehatan Lingkungan di Kelok Batuang Jorong Lubuk Selasih

Keberadaan PT. Tirta Investama (AQUA) memberikan kontribusi terhadap masyarakat Kanagarian Batang Barus . Melalui CSRnya, berbagai program ditujukan kepada masyarakat dengan manfaat yang memang sangat dirasakan oleh masyarakat. Hal ini, dibenarkan oleh Wali Nagari Batang Barus Bapak Syamsul Azwar yang turut serta merasakan manfaat dari sumbangansumbangan CSR baik fisik maupun non fisik. Tidak hanya itu, kontribusi CSR juga berpengaruh terhadap interaksi sosial warga masyarakat. Menurut penuturan Bapak Delvis Jufril selaku salah satu 
Yulia Risa, Elwidarifa Marwenny: Implementasi Tanggung jawab Sosial Perusahaan...

warga masyarakat, dengan adanya pertemuan warga dalam rangka rapat koordinasi program CSR AQUA yang akan dilaksanakan menambah intensitas pertemuan warga dan silaturahmi warga lebih terjalin dengan baik. Warga menjadi sering bertemu dalam satu meja sehingga meningkatkan komunikasi antar warga. PT. Tirta Investama, Pabrik Kayu Aro dalam pelaksanaan CSR adalah masih adanya masyarakat yang belum sadar akan kelestarian lingkungan dan pembagian wilayah prioritas program CSR karena adanya missdengan pembagian wilayah administratif Kabupaten Solok Kedepannya diharapkan PT. Tirta Investama lebih teliti dan jeli untuk memprioritaskan wilayah program CSR, tidak hanya sebatas kanagarian batang barus namum lebih luas lagi di kanagarian-kanagarian di Kabupaten Solok.

\section{SIMPULAN}

Dari hasil penelitian dan pembahasan terhadap permasalahan yang berkaitan dengan implementasi tanggung jawab sosial perusahaan (corporate social responsibility) pada PT. Tirta Investama Danone Aqua Unit Usaha Danau Kembar adalah:

1. Aspek hukum penerapan tanggung jawab sosial perusahaan (CSR) sudah diakomodir dalam berbagai bentuk regulasi di Indonesia terdapat 7 (tujuh) regulasi terkait tanggung jawab sosial perusahaan baik dalam bentuk undang-undang, peraturan pemerintah, maupun peraturan menteri. Tanggung jawab Sosial
Perusahaan/ Tanggung jawab sosial dan Lingkungan (Corporate Social Responsibility) yang dulu terdiri dari sifat mandatory dan voluntary, setelah di berlakukannya UndangUndang Republik Indonesia Nomor 25 Tahun 2007 Tentang Penanaman Modal dan Undang-Undang Nomor 40 Tahun 2007 Tentang Perseroan Terbatas berubah menjadi hanya bersifat mandatory. Hal ini bukan sekedar tranpartasi, maupun adopsi konsep CSR, tetapi merupakan bentuk Inovasi dari Pengaturan Corporate Social Responsibility jadi dengan dinormatifkannya prinsipprinsip CSR ini, maka sifat tanggung jawab menjadi mandatory.

2. Dalam pelaksanaan CSR langkah stategis yang di lakukan oleh PT. Tirta Investama Danone Aqua Plan Solok Pelaksana programnya, dipercayakan kepada mitra Perkumpulan Keluarga Berencana Indonesia (PKBI) Provinsi Sumbar, melalui lembaga ini lah CSR di laksanakan, bentuk kegiatannya di bidang sosial: melaksanakan Sanitasi Lingkungan berbasis masyarakat, konservasi berbasis masyarakat (sekolah lapangan alpukat), membangun taman keanekaragaman hayati (KEHATI), sedangkan di bidang ekonomi diberikan dalam bentuk donasi irigasi, mesjid dan berbagi hewan qurban serta membatu anak yatim di kanagarian Batang Barus. Sustainable development menjadi goal dari CSR karena bukan hanya pembangunan komunitas yang 
menjadi inti tujuan dari CSR melainkan bagaimana pembangunan tersebut bisa terus eksis berada dalam masyarakat sebagai upaya untuk keseimbangan lingkungan dan alam.

3. Hambatan yang di hadapi oleh PT Tirta Investama Danone Aqua dalam penerapan CSR adalah Masih adanya masyarakat yang belum sadar akan kelestarian lingkungan dan belum meratanya Program CSR di Kabupaten Solok di karenakan pembagian wilayah prioritas program CSR baru hanya dilakukan di sekitar wilayah perusahaan saja .

\section{UCAPAN TERIMA KASIH}

Hasil tulisan ini dapat tercapai dengan dukungan dan peranan dari berbagai pihak. Untuk itu penulis mengucapkan terima kasih yang sebesarbesarnya kepada semua pihak yang telah membantu dalam penulisan penelitian ini: Rektor Universitas Dharma Andalas, PT. Tirta Investama Danone Aqua: Bapak Staf CSR Izrai, Bapak Anton, Ibuk Dona dan Bapak Wali Nagari Syamsul Azwir dan Ibuk liza Sekretaris Nagari Kanagarian Batang Barus Kabupaten Solok. Masyarakat Kanagarian Batang Barus: Bapak Delvis Jufril, Bapak Benitos Darmawan dan ibu Andrian Ahmad Rius, serta segenap masyarakat di Kanagarian Batang Barus Kabupaten Solok.

\section{DAFTAR PUSTAKA}

Arif budimanta, Adi prasetijo, Bambang Rudito, 2006, Coorporate Social Responsibility Alternatif Bagi Pembangunan Indonesia, ICSD, Jakarta.

AB Susanto, 2007, Coorporate Social Responsibility: A Strategic Management Approach, Jakarta Consulting Gruop, Jakarta.

Isa wahyudi dan Busyra Azheri, 2008, Coorporate Social Responsibility: Prinsip, pengaturan dan Implementasi, In-Trans Publising, Malang.

Marsono, 2006, Kemajuan Terkini Penelitian, Revitalsasi Kearifan Lokal Guna Mewujudkan masyarakat Sejahtera, Seminar Klaster Riset, LPPM UGM, Yogyakarta.

BusyraAzheri, 2010, Disertasi, Tanggung Jawab Sosial Perusahaan Dalam Kegiatan Pertambangan Di Sumatera Barat. Fakultas Hukum Universitas Brawijaya Malang.

Teguh, 2006, Tanggung Jawab Sosial Harus Dilakukan, makalah pada seminar "Corporate Social Responsibility”: Integreting Social Aspect into The Business, Ikatan Keluarga Mahasiswa Manajemen Universitas Gajah Mada (UGM), Yogyakarta.

Soetandyo Wignjosoebroto, 1995, Makalah, Sebuah Pengantar ke Arah Perbincangan tentang Pembinaan Penelitian Hukum dalam PJP II; BPHN Departemen Kehakiman. 
Yulia Risa, Elwidarifa Marwenny: Implementasi Tanggung jawab Sosial Perusahaan...

Marsono, 2006, Kemajuan Terkini James Midgley, 2007, Growth, Penelitian, Revitalsasi Kearifan Lokal Guna Mewujudkan masyarakat Sejahtera, Seminar Klaster Riset, LPPM UGM, Yogyakarta. Redistribution, and Welfare, Towar Social Invesment, dalam Dhaniswara K. Harjono, Hukum Penanman Modal, Rajawali Press, Jakarta. 